\title{
THE MANUFACTURE OF THE PROTOTYPE FIXED CRANE HARBOR AS THE ADDER DEVICE INSIGHT FOR CRANE OPERATOR NOVICE
}

\author{
Atmiasri*, Angga Agus Prautomo \\ Department of Electrical Engineering \\ University of PGRI Adi Buana Surabaya \\ *Corresponding email address: atmi.asri@yahoo.com
}

\begin{abstract}
Fixed cranes are tools used in the process of loading and unloading containers/materials from trucks and vice versa. Most of the young crane (beginners) operators in the port area are still unfamiliar in carrying out these tools, therefore the authors conduct research to make the fixed prototype crane that has functions and controls (including joystick) that allows the original device to remain valid. Insight enhancers in using real fixed cranes. The circuit built from Arduino Uno, DC motor (Gear Hoist and Gear Slewing), servo motor, and joystick as input for motion controllers from all systems. Fixed crane prototypes that have been made above are the best of the hoist system or the best slewing system to determine the load that can be carried by the system. From the results of these calculations that the prototype fixed crane made has a maximum carrying capacity in terms of hoist and slewing of 90 grams.
\end{abstract}

Keywords: carrying capacity, fixed crane, hoist, slewing

\section{INTRODUCTION}

Fixed crane is one of tool that are obviously found in the large building construction. According to Oxford dictionary on tam, 2011, a fixed crane is a high machine that's function for moving a heavy thing by hang them from arm the fixed crane [1].

In the fixed crane there are technical term about hoist, slewing and lufting. Hoist is a system for pulling or to go down a thing that is pulled and discharge by a crane [2]. Slewing is a system for moving the up body on crane by circle performance 360 degree, lufting is a work system that's like human arm, the function is for jack up or as a helper hoist system for lift up or discharge a thing [3].

Before author make the prototype, fixed crane there is also one of the college students of Universitas Muhammadiyah Surabaya manufacture a crane that is prototype RTG (Rubber Tired Gantry) that's functions for take container from truck and put it on the container field and just the opposite [4]. But be different with author do, fixed crane that's function as loading and unloading container from ship to truck and just the opposite. From that the author make prototype fixed crane for increase insight the new operator that will work embrace crane world [5].

Set of problem how to making this prototype fixed crane can more maximized the function and the purpose so can lift up a heavy thing, until this tool can give ease for new operator trainer so can study and operate prototype fixed crane well [6].

The purpose of this scientific article is making a tool on prototype from the original form by used joystick controller inside operate the fixed crane system for learning trainer operator that will work in fixed crane world. And to do a test for now the strength prototype fixed crane that's the author make [7].

\section{RESEARCH METHODS}

In the manufacture of this scientific article the author many search of reference in matter how to make a prototype fixed crane that's operate by joystick controller dan setting the circle motor by drive until ease in each agencies company for the official that can learning each and every system at prototype fixed crane before operate the real crane and for the student will can know and fast understand every system at prototype fixed crane. 
Manufacture of this prototype require right calculation will the tool can work as it should be and resemble the real crane, it requires a strength material than can lift up the right load.

Design system at this tool started by determine the design specification that's agree with the background, choose the manufacture technique that's efficient and effective, until ease in hardware and software design at this harbor prototype fixed crane.

Steps of this design manufacture prototype fixed crane started from preparation of materials and tools, manufacture the foot retaining of fixed crane, manufacture lower body fixed crane, manufacture system hardware slewing fixed crane, manufacture system hardware hoist fixed crane, pulley installation and string for towing load couple with hoist, upper body and lufting, manufacture upper body fixed crane, manufacture lufting hardware system fixed crane then finished

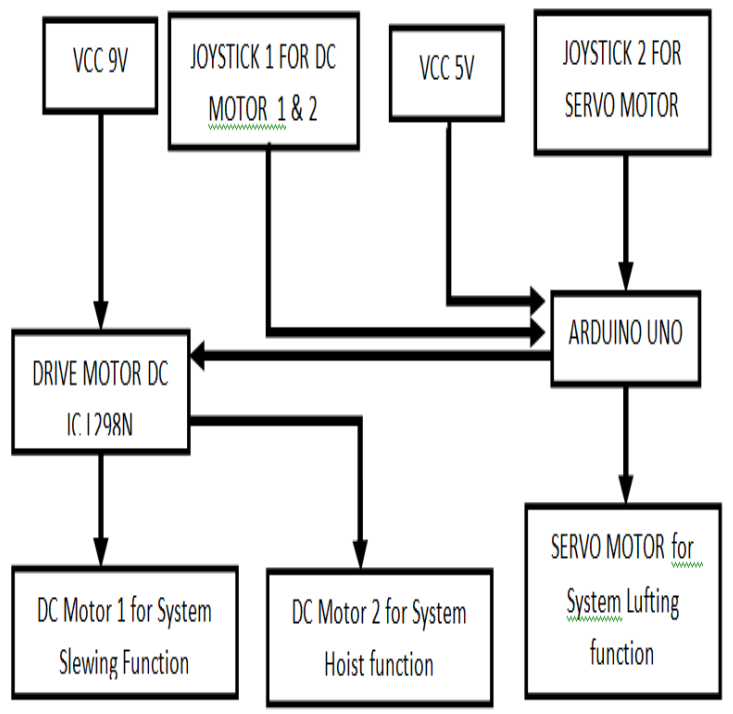

Picture 1. Block diagram of the system

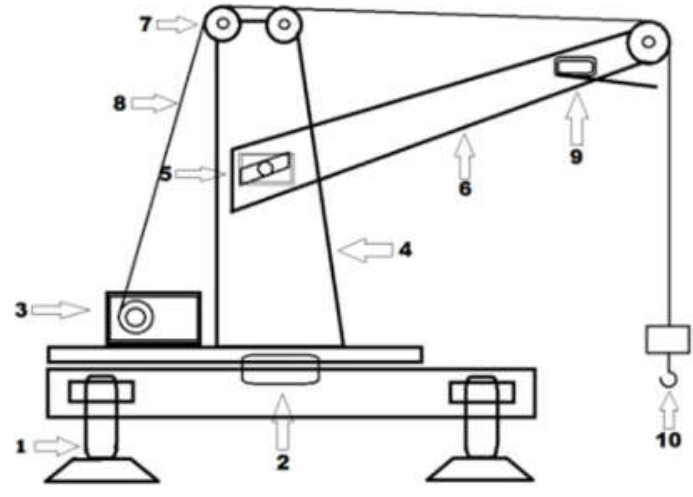

Picture 2. A sketch of the prototype fixed port crane

On picture number 2 there is number the show schematic supporting components appointment of harbor prototype fixed crane. Number " 1 " is foot retaining fixed crane. On number " 2 " is DC motor 1 that's function moving slewing system for whirl upper body. On number " 3 " is DC motor 2 that's function moving hoist system for pull the load on the rope couple at pulley upper body and lufting. On number " 4 " is upper body. On number " 5 " is servo motor that's function as lufting system. On number " 6 " is the lufting body. On number " 7 " is pulley picture that's function as player the pull of the rope. On number " 8 " is pull rope. On number "9" is limit switch stopper. On number " 10 " is hook for lift up the load or a thing.

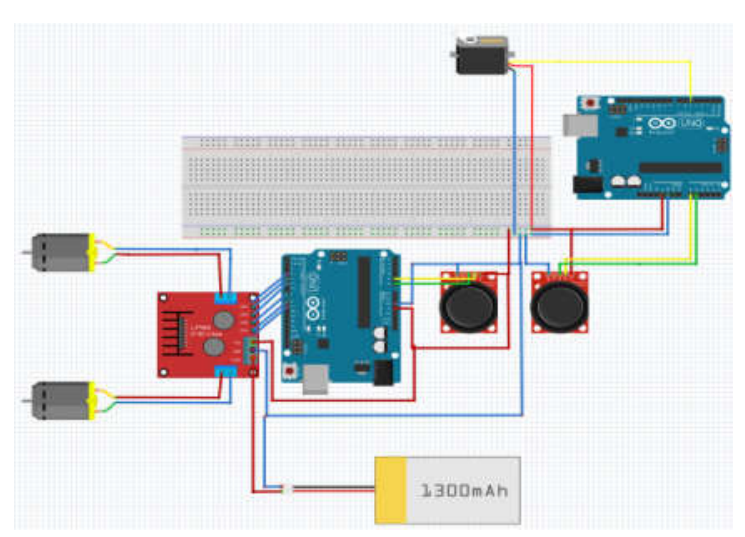

Picture 3. Series DC motor speed control gear and a servo motor.

On picture 3 described work principle at setting the speed of DC motor it started from input voltage 5-volt DC incoming the input 
BEST

Journal of Applied Electrical, Science, \& Technology - University of PGRI Adi Buana Surabaya

p-ISSN 2715-2871

e-ISSN 2714-5247

joystick. Arduino Uno and Servo Motor, inside joystick exist 2 output that is joyX and joyY that connect to arduino uno at analog input $\mathrm{A} 0$ and $\mathrm{A} 1$, joyX output sign in to analog input $\mathrm{A} 0$ and joyY output sign in to analog input A1 then process by arduino uno, at enable motor and PWM signal that process by aruino uno at terminal digital input $3,4,5,7,8$ and 9 will connected to IC L298N driver at terminal EnA,In1,In2,In3,In4, EnB, at terminal digital input arduino uno number 3 sign in to EnA driver terminal for enable motor $\mathrm{A}$, number 4 sign in to In4 driver terminal for PWM signal motor A, number 5 sign in to In3 driver terminal for PWM signal motor $\mathrm{B}$, number 8 sign in to In1 driver terminal for PWM signal motor B, number 9 sign in to $\mathrm{EnB}$ driver terminal for enable motor B, then process by IC LN298N driver for turn on the work function of DC motor Gear and don't forget to give 9 volt DC power supply to IC L298N driver series.

And for working system servo motor is started by give 5 volt DC to joystick, then joyX output from joystick sign in to analog input $\mathrm{A} 0$ at arduino uno for process moving servo motor system, inside servo motor there are 3 cable, that are red cable ( 5 VDC supply), blue cable (GND), and yellow cable (signal), at yellow cable sign in to terminal arduino uno number 5 that first must be include program the signal at arduino uno program(IDE) by measure of servo motor circle 0-180 degree.

The independent variable that is variable that can influence change and variation values of the dependent variable, in this research the independent variable from the research title is the power of torque DC motor gear at hoist system for lift up a thing and DC motor gear at slewing system for circle upper body at prototype fixed crane.

The dependent variable is variable that the values depending of the variation from the independent variable change. In this research the dependent variable is the weight of the object that will lift up by hoist system by the maximum capacity is 100 grams.

In the planning and manufacture of this tool system, the author plan and make tool at electrical engineering laboratory University
PGRI Adi Buana, sardjijo building, on street dukuh menanggal XII/4 Surabaya.

By used joystick can ease to control the circle servo motor and DC motor gear measure right and left and setting the speed round on DC motor gear by used PWM system (Pulse with Modulation). For the size of the power of torsi on servo motor and DC motor gear look from construction at gear box motor and power horse at that motor. By used driver motor IC L298N can help the performance of the speed loop on motor and can setting to and fro loop of that motor DC gear.

\section{RESULTS AND DISCUSSION}

Examine how the strength of this harbor prototype fixed crane to can lift up a thing and how big the capacity that can lift up by this harbor prototype fixed crane. The author using digital scales (gram) for knowing the load capacity that will testing on harbor prototype fixed crane.

Table 1. The result of the output voltage of the DC motor gear hoist speed 50\%(low)

\begin{tabular}{|c|c|c|c|}
\hline No. & $\begin{array}{c}\text { V Hoist Up } \\
\text { Output Motor } \\
\text { DC Gear }\end{array}$ & $\begin{array}{c}\text { V Hoist Down } \\
\text { Output Motor } \\
\text { DC Gear }\end{array}$ & Load \\
\hline 1. & $3,37 \mathrm{~V}$ & $4,29 \mathrm{~V}$ & 30 gram \\
\hline 2. & $3,56 \mathrm{~V}$ & $4,29 \mathrm{~V}$ & 40 gram \\
\hline 3. & $3,51 \mathrm{~V}$ & $4,56 \mathrm{~V}$ & 50 gram \\
\hline 4. & $3,74 \mathrm{~V}$ & $4,69 \mathrm{~V}$ & 60 gram \\
\hline 5. & $3,33 \mathrm{~V}$ & $4,68 \mathrm{~V}$ & 70 gram \\
\hline 6. & $3,16 \mathrm{~V}$ & $4,90 \mathrm{~V}$ & 80 gram \\
\hline 7. & $1,81 \mathrm{~V}$ & $4,61 \mathrm{~V}$ & 90 gram \\
\hline 8. & $1,56 \mathrm{~V}$ & $2,86 \mathrm{~V}$ & 100 gram \\
\hline
\end{tabular}


BEST

Journal of Applied Electrical, Science, \& Technology - University of PGRI Adi Buana Surabaya

Table 2. The result of the output voltage of the DC motor gear hoist speed $100 \%$ (high)

\begin{tabular}{|c|c|c|c|}
\hline No. & $\begin{array}{c}\text { V Hoist Up } \\
\text { Output Motor } \\
\text { DC Gear }\end{array}$ & $\begin{array}{c}\text { V Hoist Down } \\
\text { Output Motor } \\
\text { DC Gear }\end{array}$ & load \\
\hline 1. & $1,71 \mathrm{~V}$ & $2,51 \mathrm{~V}$ & 30 gram \\
\hline 2. & $1,93 \mathrm{~V}$ & $2,63 \mathrm{~V}$ & 40 gram \\
\hline 3. & $2,08 \mathrm{~V}$ & $2,95 \mathrm{~V}$ & 50 gram \\
\hline 4. & $2,12 \mathrm{~V}$ & $3,07 \mathrm{~V}$ & 60 gram \\
\hline 5. & $2,24 \mathrm{~V}$ & $2,75 \mathrm{~V}$ & 70 gram \\
\hline 6. & $2,99 \mathrm{~V}$ & $2,41 \mathrm{~V}$ & 80 gram \\
\hline 7. & $2,60 \mathrm{~V}$ & $2,33 \mathrm{~V}$ & 90 gram \\
\hline 8. & $1,56 \mathrm{~V}$ & $2,86 \mathrm{~V}$ & 100 gram \\
\hline
\end{tabular}

Table 3. The result of the output voltage of the DC motor gear slewing speed $50 \%$ (low)

\begin{tabular}{|c|c|c|c|}
\hline No. & $\begin{array}{c}\text { V Slewing Left } \\
\text { Output Motor } \\
\text { DC Gear }\end{array}$ & $\begin{array}{c}\text { V Slewing Right } \\
\text { Output Motor DC } \\
\text { Gear }\end{array}$ & load \\
\hline 1. & $3,63 \mathrm{~V}$ & $3,63 \mathrm{~V}$ & 30 gram \\
\hline 2. & $3,66 \mathrm{~V}$ & $3,66 \mathrm{~V}$ & 40 gram \\
\hline 3. & $3,93 \mathrm{~V}$ & $3,93 \mathrm{~V}$ & 50 gram \\
\hline 4. & $4,20 \mathrm{~V}$ & $4,20 \mathrm{~V}$ & 60 gram \\
\hline 5. & $4,11 \mathrm{~V}$ & $4,11 \mathrm{~V}$ & 70 gram \\
\hline 6. & $5,29 \mathrm{~V}$ & $5,29 \mathrm{~V}$ & 80 gram \\
\hline 7. & $5,11 \mathrm{~V}$ & $5,11 \mathrm{~V}$ & 90 gram \\
\hline 8. & $5,61 \mathrm{~V}$ & $5,61 \mathrm{~V}$ & 100 gram \\
\hline
\end{tabular}

Table 4. The result of the output voltage of the DC motor gear slewing speed $100 \%$ (high)

\begin{tabular}{|c|c|c|c|}
\hline No. & $\begin{array}{c}\text { V Slewing } \\
\text { Left } \\
\text { Output Motor } \\
\text { DC Gear }\end{array}$ & $\begin{array}{c}\text { V Slewing } \\
\text { Right } \\
\text { Output Motor } \\
\text { DC Gear }\end{array}$ & Load \\
\hline 1. & $6,61 \mathrm{~V}$ & $6,61 \mathrm{~V}$ & 30 gram \\
\hline 2. & $6,56 \mathrm{~V}$ & $6,56 \mathrm{~V}$ & 40 gram \\
\hline 3. & $6,49 \mathrm{~V}$ & $6,49 \mathrm{~V}$ & 50 gram \\
\hline 4. & $6,43 \mathrm{~V}$ & $6,43 \mathrm{~V}$ & 60 gram \\
\hline 5. & $6,54 \mathrm{~V}$ & $6,54 \mathrm{~V}$ & 70 gram \\
\hline 6. & $6,41 \mathrm{~V}$ & $6,41 \mathrm{~V}$ & 80 gram \\
\hline 7. & $6,61 \mathrm{~V}$ & $6,61 \mathrm{~V}$ & 90 gram \\
\hline 8. & $6,00 \mathrm{~V}$ & $6,00 \mathrm{~V}$ & 100 gram \\
\hline
\end{tabular}

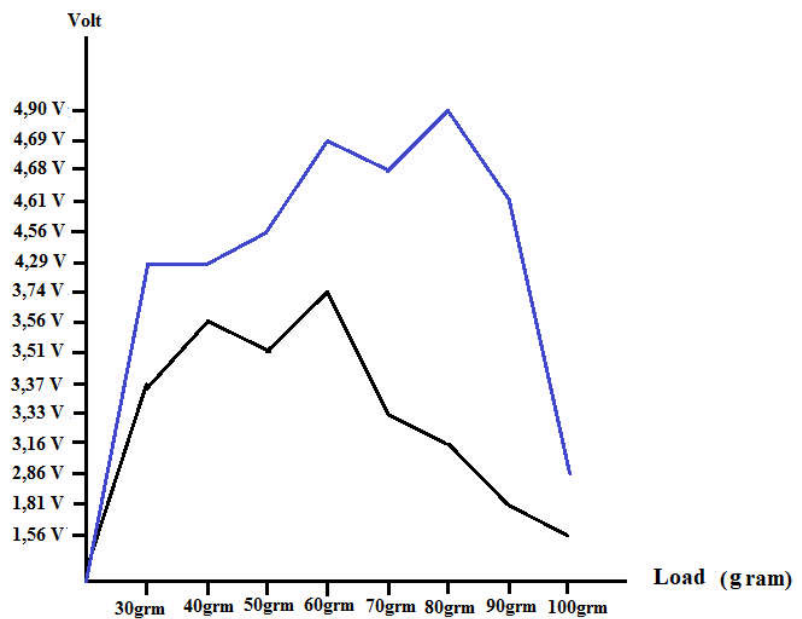

Picture 4. Chart result of output voltage of the DC motor gear hoist 50\% (low)

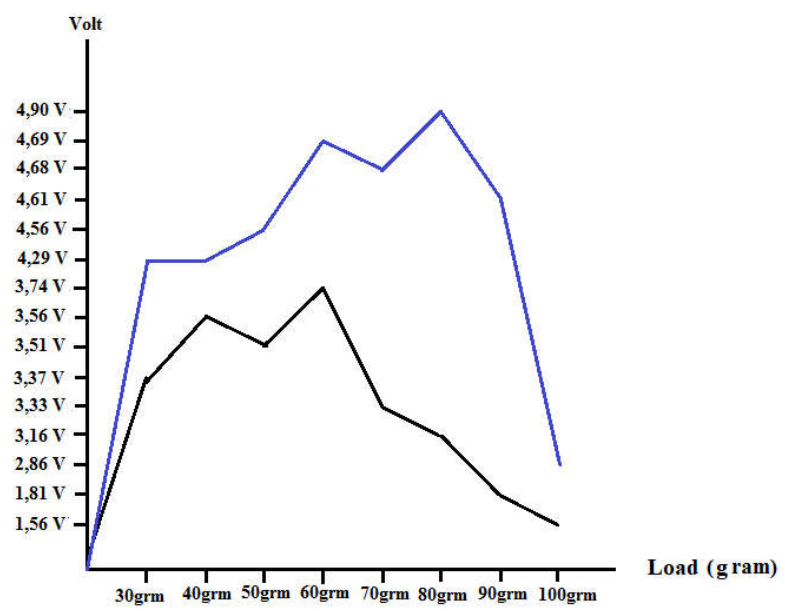

Picture 5. Chart result of output voltage of DC motor gear hoist $100 \%$ (high)

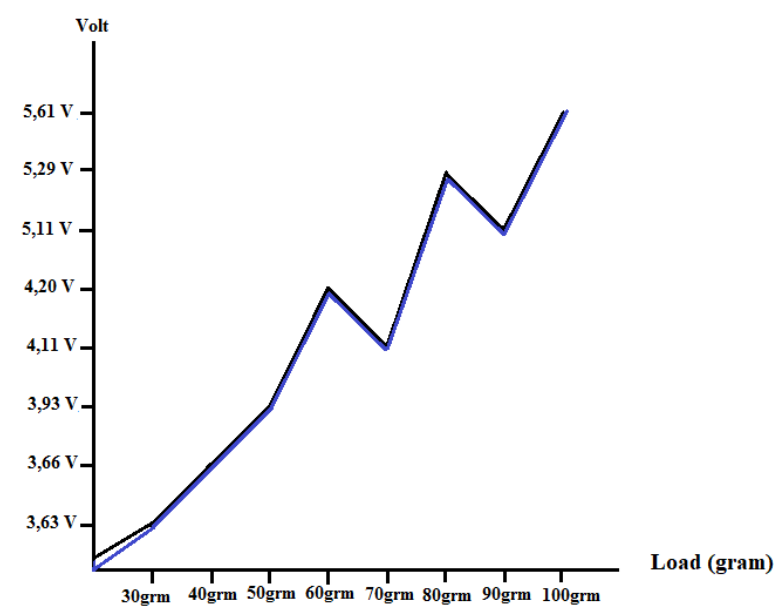

Picture 6. Chart result of output voltage of DC motor gear slewing 50\% (low) 


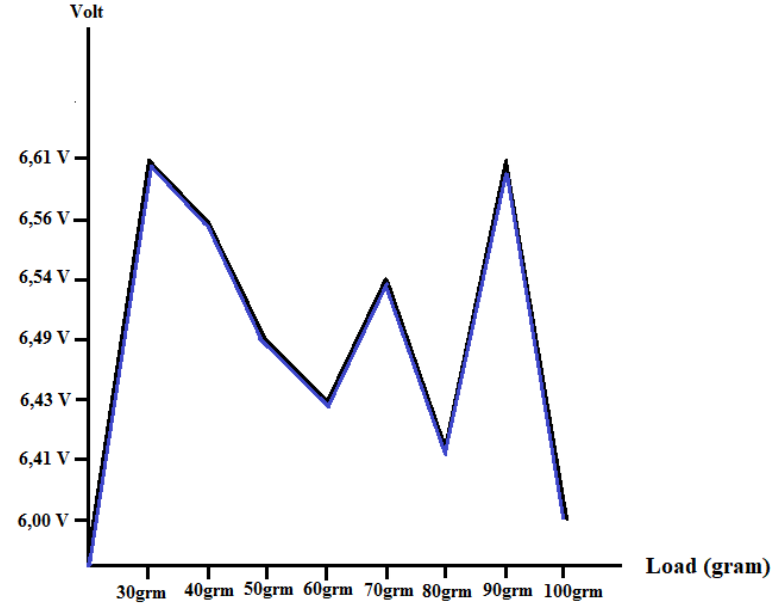

Picture 7. Chart result of output voltage of DC motor gear slewing 100\%(high)

The results of this discussion arduino uno is able to regulate the speed of $\mathrm{dc}$ motor gear to work with as desired the author, with control through a joystick and then processed the arduino uno too set the rotation speed of the DC motor gear which is then processed by the drive IC L298N to setting the motor rotation right and left, and also the arduino uno is able to set degrees of rotation of the motor of the servo tool is able to work with lifting weights only 90 grams with the results of the testing tool can be seen in the ability of the prototype fixed crane port, by using DC motor gear that uses a voltage of 6 volts and the torque is $0.8 \mathrm{~kg}$ for hoist and slewing system and servo with a voltage of 5 volts and a torque of up $8 \mathrm{~kg}$. This tool is able to useful, employees of a company as a vehicle for learning to be able to know the system of a crane that is a prtotype function of the crane the protbased arduino uno by using drive motor and controller joystick.

\section{CONCLUSION}

The author has managed to make a prototype fixed crane minimalism which has the function and control using a joystick that resembles the original device based on the results of the variation of loading stating that the prototype fixed crane that is built to have a carrying capacity of maximum load of 90 grams in a technical prototype fixed crane port can be one of the containers learning trainer operator novice or young who previously did not understand the system to work on fixed port crane real.

\section{ACKNOWLEDGMENT}

The author would like to thank you for Mr. Drs. H. Sugito, S.T., M.T. as well as the mother of the head of the study program of technical engineering Atmiasri, S.T, M.T. University PGRI Adi Buana Surabaya, that for the guidance the author was able to complete a scientific article.

\section{REFERENCE}

[1] Kadir, Abdul. 2012. "Panduan Praktis Mempelajari Aplikasi Mikrokontroller dan Pemogramannya menggunakan Arduino". C.V.ANDI Offset. Yogyakarta.

[2] Syahwil, Muhammad. 2014. "Panduan Mudah Simulasi Dan Praktek Mikrontroller Arduino". C.V. ANDI offset. Yogyakarta.

[3] Bambang Setiyobudi. 2012. "Prinsip Kerja Motor DC".

[4] Lister, Eugene C.. 1993. "Mesin Dan Rangkaian Listrik Edisi Keenam". Erlangga Jakarta.

[5] Andrianto, H.. 2008. "Fungsi IC L298N Buku Data Sheet IC L298N".

[6] Pranastya, A.L., Muti'ah, A.D., 2014. K"SOLUSI PENCEGAHAN KECELAKAAN KERJA PADA TOWER CRANE DENGAN SISTE, KENDALI REMOTE CONTROL". Program Kreat. Mhs.-Karsa Cipta 0.

[7] Triatmojo, Bambang. Beta offset, 2009."Perencanaan Pelabuhan". 